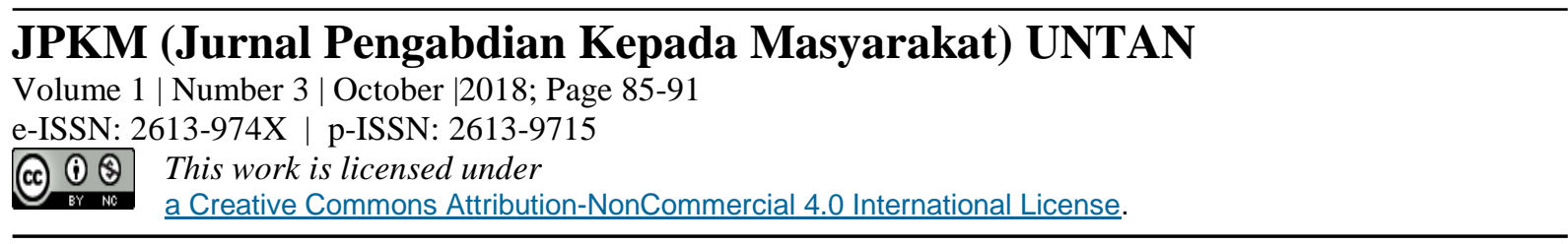

\title{
Thematic Learning Training Based on 2013 Curriculum for Primary School Teachers
}

\author{
Siti Halidjah $^{1}$, Tahmid Sabri ${ }^{2}$, K.Y Margiati ${ }^{3}$, Endang Uliyanti ${ }^{4}$ \\ Universitas Tanjungpura, Pontianak, Indonesia \\ sitihalidjah_pgsd@yahoo.co.id
}

Keywords :

Thematic Learning, 2013

Curriculum

\begin{abstract}
The purpose of this Community Service is to provide an understanding of the implementation of curriculum-based thematic learning. The teachers involved numbered 30 people and were representatives from several schools. The method of the activities carried out in the form of training and counseling by displaying competent speakers and models in terms of compiling and implementing thematic learning based on 2013 Curriculum. The results of community service activities that have been carried out are better understanding of teachers on 2013 curriculum based thematic learning for primaryschool teachers. For teachers who teach in classes that have implemented the 2013 curriculum, this activity can be good learning in order to apply the 2013 Curriculum in the classroom.
\end{abstract}

\section{INTRODUCTION}

The purpose of this Community Service is to provide an understanding of the implementation of curriculum-based thematic learning. The teachers involved numbered 30 people and were representatives from several schools. The method of the activity carried out in the form of training and counseling by displaying resource persons and competent models in terms of compiling and implementing learners Thematic learning is integrated learning that uses themes to link several subjects so as to provide meaningful experiences to students. The theme is the main subject or idea that is the subject of discussion. The benefits that can be obtained in thematic learning are (1) by combining several basic competencies and indicators and the contents of the subjects will occur savings, because the overlap of material can be reduced and even eliminated, (2) students are able to see meaningful relationships between subjects, (3) learning is intact so that students will get an understanding of processes and material that are not fragmented, and (4) with the integration of subjects, the mastery of concepts will be better and improved.

The 2013 curriculum has been running for approximately three years. Within three years, improvements have also been made. Refinement is carried out covering several aspects, one of which is the teacher's understanding of the preparation of the learning plan. The implementation of the curriculum is regulated in various regulations of the Minister of Education and Culture. The successful implementation of Curriculum 2013 at the primaryschool level in learning activities in the classes according to what the government and the community expect is largely determined by the understanding of stakeholders, especially teachers. Primary school teachers must have understanding, awareness, ability, creativity, patience, and tenacity.

The 2013 curriculum is a curriculum based on thematic learning. The learning theme has 
been set according to the grade level. Based on the results of observations, there are still teachers who have not been able to carry out thematic learning in accordance with the 2013 curriculum. To implement the curriculum to fit the design, some readiness is needed, especially the readiness of the implementer. No matter how good the design or design of the curriculum is, but its success depends on the teacher. Even a simple curriculum if the teacher has the ability, enthusiasm, and high dedication results will be better than the great curriculum design. However, the ability, enthusiasm, and dedication of the teacher are low. The teacher is the main key to educational success. Other resources are also the key to the success of education, but the main key lies in the teacher.

Curriculum implementation actually occurs during the teaching and learning process. The learning process is a process that contains a series of actions by the teacher and students on reciprocal relationships that take place in an educational situation to achieve certain goals, in the process, there is a multi-teacher teacher. The role of the teacher with regard to curriculum planning is the teacher making a plan for implementing learning (Lesson Plan) and implementing it according to planning.

Based on the observation of the author in looking at the implementation of the program to improve the teacher education qualifications in the primary teacher education Study Program, primaryschool teachers were still found who were unable to understand and carry out thematic learning in accordance with the 2013 curriculum. Their various complaints revealed the difficulty of carrying out these thematic learning.

On the basis of the above conditions, an effort is needed to overcome the difficulties of the teacher in conducting thematic learning in accordance with the 2013 curriculum. The solution that can be given is to provide 2013 curriculum-based thematic learning training for primaryschool teachers. The training activities are intended as job training which broadly covers the activities of (1) training in the preparation of lesson plan, (2) giving examples of the implementation of 2013 curriculum-based thematic learning. Thus, the community service activities are expected to contribute to the improvement of school teachers' understanding the basis for implementing 2013 curriculum-based thematic learning.

The selection of schools for community service locations in Pal Sembilan Village / Sungai Kakap Sub-District is based on the consideration that the schools in this region in the future will be the internship program of primary teacher education of Faculty of Teacher Training and Education in Universitas Tanjungpura partner schools. In addition, the school welcomed the intention of the primary teacher education community service team to carry out activities at the primaryschool. Based on the background, the problem in this community service is how the teacher's understanding of the implementation of 2013 Curriculum-based thematic learning is? The purpose of this community service is to provide an understanding of the implementation of 2013 curriculum based thematic learning.

Thematic learning is learning that uses themes in linking several subjects so as to provide meaningful experiences to students. It is said to be meaningful because, in thematic learning, students will understand the concepts they learn through direct experience and relate them to other concepts that they have understood. This approach departs from the theory of learning which rejects the process of training / memorization (drill) as the basis for forming children's intellectual knowledge and structure. This learning theory is driven by Gestalt Psychology leaders, including Piaget, who emphasized that learning must be meaningful and oriented to the needs and development of children. Thematic learning approach emphasizes the application of the concept of learning while doing something (learning by doing).

In its implementation, this thematic learning approach departs from a theme chosen and developed by the teacher with students by paying attention to the relevance of the subject matter. Themes are the subject matter, the basis of the story (which is spoken, is used as the basis for composing, changing poetry, etc. (Ministry of National Education, 2008: 1429). With the theme it is expected to provide many benefits, including (1) students easily focus on a particular theme , (2) students are able to learn knowledge and develop various basic competencies between subjects in the same theme, (3) understanding of subject matter more deeply and impressively, (4) basic competencies can be developed better by linking other subjects with students' personal experiences, (5) students are able to feel the benefits and meaning of learning more because the material is presented in the context of a clear theme, (6) students are more passionate about learning because 
they can communicate in real situations, to develop abilities in one subject while learning other subjects, and ( 7) teachers can save time because subjects thematically presented can be prepared $n$ at the same time and given in two or three meetings, the remaining time can be used for remedial activities, stabilization, or enrichment.

Thematic learning can be interpreted as a learning activity by integrating material in several subjects in one topic / topic of discussion. Sutirjo and Sri Istuti Mamik (2005: 6) state that thematic learning is an effort to integrate knowledge, skills, values, or learning attitudes, as well as creative thinking using themes

Some of the distinctive features of thematic learning include (1) experience and learning activities are very relevant to the level of development and needs of primaryschool age children, (2) activities chosen in the implementation of thematic learning depart from the interests and needs of students, (3) learning will be more meaningful and memorable for students so that learning outcomes can last longer, (4) help develop students' thinking skills, (5) present pragmatic learning activities in accordance with problems often encountered by students in their environment, and (6) develop skills, social students, such as cooperation, tolerance, communication, and being responsive to other people's ideas.

With the implementation of learning by utilizing this theme, several benefits will be obtained, namely: (1) By combining several basic competencies and indicators as well as the contents of the subject there will be savings, because overlapping material can be reduced or even eliminated, (2) Students are able to see relationships meaningful because the content / learning material has more role as a tool or tool, not the final goal, (3) Learning becomes intact so that students will get an understanding of processes and material that are not fragmented (4) With the integration of lessons, mastery of the concept will get better and increasing.

The implementation of thematic learning is the implementation of the applicable curriculum. When considering the implementation of this learning based on a philosophical foundation, psychological foundation, and juridical foundation.

The philosophical foundation of the implementation of thematic learning is strongly influenced by the three schools of philosophy, namely: (1) progressivism, (2) constructivism, and (3) humanism. The flow of progressivism views the learning process needs to be emphasized in the formation of creativity, giving a number of activities, natural atmosphere (natural), and paying attention to the student experience. The flow of constructivism sees direct experience as a key in learning. According to this school, knowledge is the result of human construction or formation. Humans construct their knowledge through interaction with objects, phenomena, experiences and their environment. Knowledge cannot be transferred from teacher to student but must be interpreted by each student. Knowledge is not something that is ready, but a process that develops continuously. The activity of students manifested by their curiosity is very instrumental in the development of their knowledge. The flow of humanism sees students in terms of their uniqueness / specificity, potential, and motivation. Students besides having similarities also have specialties. The psychological foundation is mainly related to the psychology of student development and the psychology of learning. Developmental psychology is needed especially in determining the content / thematic learning material given to students so that the level of breadth and depth is in accordance with the developmental stages of the students. Learning psychology contributes to how the content / thematic learning material is conveyed to students and how students must learn it. Through thematic learning, it is expected that there will be changes in student behavior towards maturity, both physical, mental / intellectual, moral and social.

The juridical foundation relates to various policies or regulations that support the implementation of thematic learning in primaryschools. In Law No. 23 of 2002 concerning Child Protection states that every child has the right to obtain education and teaching in the context of his personal development and the level of his intelligence in accordance with his interests and talents. In Law No. 20 of 2003 concerning the National Education System states that each student in each education unit has the right to receive educational services in accordance with their talents, interests, and abilities.

Thematic learning has characteristics or characteristics. namely (1) student-centered, (2) providing direct experience to students, (3) the separation of subjects is not very clear, (4) presenting concepts from various subjects in a learning process, (5) being flexible, and (6) learning outcomes 
can develop according to the interests and needs of students. In order to obtain a clearer picture of these characteristics can be described as follows.

1. Student-Centered

Thematic-centered learning is student-centered (student-centered), this is in accordance with the modern learning approach which places students more as the subject of learning while the teacher acts more as a facilitator, namely providing convenience to students in conducting learning activities.

2. Provide direct experience

Thematic learning can provide direct experiences to students (direct experiences). With this direct experience, students are faced with something tangible (concrete) as a basis for understanding things more abstractly.

3. The separation of subjects is not very clear

In thematic learning, the separation between subjects becomes less clear. The focus of learning is directed at discussing the themes that are most closely related to student life.

4. Presenting concepts from various subjects

Thematic learning presents concepts from various subjects in a learning process. Thus, students are able to understand these concepts in their entirety. This is needed to help students solve problems faced in everyday life.

5. Flexible

Thematic learning is flexible (flexible) where the teacher can associate teaching material from one subject to another, even linking it to student life and the environment in which the school and students are located.

6. Learning outcomes are in accordance with the interests and needs of students

Students are given the opportunity to optimize their potential according to their interests and needs.

7. Use the principle of learning while playing and fun.

The lesson plan is a plan for face-to-face learning activities for one or more meetings. The lesson plan is developed from syllabus to direct learning activities of students in an effort to achieve Basic Competency. According to Al Tabany (2014: 255), Lesson plan includes plans for developing procedures and learning organization, so that one basic competency is determined in the standard content of each subject, as described in the syllabus.

Every educator in the education unit is obliged to prepare lesson plans in a complete and systematic manner so that learning takes place interactively, inspiring, fun, challenging, efficient, motivating students to participate actively, and providing sufficient space for initiative, creativity, and independence according to talent, interests and physical and psychological development of students. The lesson plan is arranged based on the basic competency or sub-theme that is holding meetings or more.

The thematic lesson plan components according to the 2013 curriculum (Ministry of Education and Culture, 2015: 9-12) are as follows.

1. School identity, namely the name of the education unit.

2. Subject identity or theme / sub-theme; class / semester; subject matter.

3. Allocation of time is determined according to the requirements for achieving basic competency and the burden of learning by considering the number of hours of lessons available in the syllabus and the basic competency that must be achieved.

4. Learning objectives are formulated based on basic competency, using operational verbs that can be observed and measured, which includes attitudes, knowledge, and skills.

5. Basic competencies and indicators of achievement of competence.

6. Learning material contains relevant facts, concepts, principles, and procedures, and is written in the form of items in accordance with the formulation of indicators of competency achievement;

7. Learning methods, used by educators to realize the learning atmosphere and the learning process so that students reach the level that is tailored to the characteristics of students and what will be achieved.

8. Learning media, in the form of a learning process, aids for delivering subject matter.

9. Learning resources can be in the form of books, print and electronic media, the environment, or other relevant learning resources. 
10. The steps of learning are carried out through the preliminary, core, and closing stages.

11. Assessment of learning outcomes.

The order of the lesson plan components above is not a standard sequence, but all components of the lesson plan must be completely contained in the learning plan made. When preparing lesson plan, the order of components can be agreed upon in each education unit.

\section{METHOD}

The form of this community service is training on the implementation of 2013 curriculum based thematic learning. Problem-solving is done by (1) determining resource persons who have the ability according to the theme of the activities to be carried out, (2) determining the model to provide examples of 2013 curriculum based thematic learning, ) provide thematic training based on 2013 curriculum, and (4) provide examples of the implementation of 2013 curriculum-based thematic learning.

The training participants numbered 35 people consisting of class teacher representatives who taught in grades $1,2,4$, and 5. The training participants came from schools that joined one group. The form of activity chosen by the community service team of primary teacher education of Faculty of Teacher Training and Education in Universitas Tanjungpura about the implementation of 2013 curriculum based thematic learning was training and counseling. Participants are given general explanations or information about the preparation of the 2013 Curriculum-based thematic learning plan implementation with the preparation of teaching materials, students worksheet, and learning media. After that, an example of the implementation of learning is conducted with a duration of 30 minutes. The training was held on Saturday 22 September 2018 at $08.00-12.00$ WIB at SDI Nahdlatul Ulum, having its address at Jalan Kalimas Hulu 043/012 Pal 9 Sungai Kakap, Kubu Raya Regency.

The target audience in this activity is primaryschool teachers who are primaryschool teachers who have not and have implemented 2013 Curriculum-based thematic learning. For schools that have not implemented the 2013 Curriculum, all teachers are included, while only representatives of the 2013 Curriculum have been selected. 1, 2, 4, and 5. community service activities carried out are related to, among others (1) classroom teachers or subject teachers, (2) schools that have not and have implemented 2013 curriculum based thematic learning, (3) District National Education Service Kubu Raya is expected to be able to support the implementation of programmed training activities, and (4) Tanjungpura University of Pontianak, especially Faculty of Teacher Training and Education of Basic Education Department, Primary School Education Study Program in implementing Tri Darma of the college, one of which is to serve the community. The method used in community service activities is training and counseling by displaying competent speakers and models in terms of compiling and implementing thematic based curriculum 2013 curriculum in primaryschools.

\section{RESULTS AND DISCUSSIONS}

\section{A. Results}

The 2013 Curriculum-based thematic learning training for primaryschool teachers was held on Saturday 22 September 2018. The activities began at 08.00-12.00 WIB at SDI Nahdlatul Ulum. The activity was attended by 35 participants. The speakers in the socialization program were representatives of the community service team of primary teacher education lecturer of Faculty of Teacher Training and Education in Universitas Tanjungpura and one model teacher in charge of providing examples of 2013 curriculum based thematic learning. 


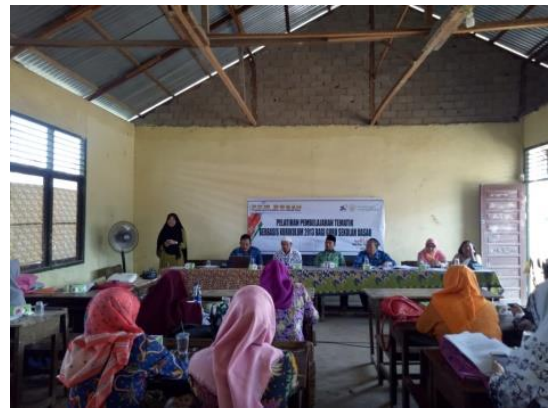

Fig. 1 Opening Activities

The socialization and training activities were welcomed by the teachers. The number of teachers presents according to the planned quota. The teacher orderly follows the event and carefully listens to the explanations of the speakers.

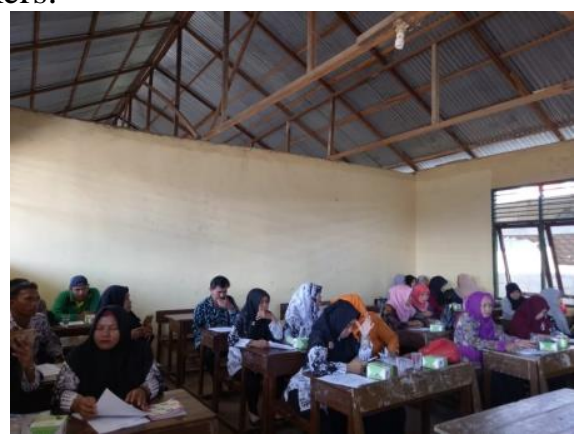

Fig. 2 Training Participants

The activity is divided into two sessions. The first session, an explanation of how to compile and sample 2013 Curriculum based thematic learning plans. The second session, participants observed examples of thematic learning in accordance with the examples of learning plans that have been delivered. When observing learning, participants are given examples of learning plans that are displayed. After completion, participants are asked to comment on the learning displayed.

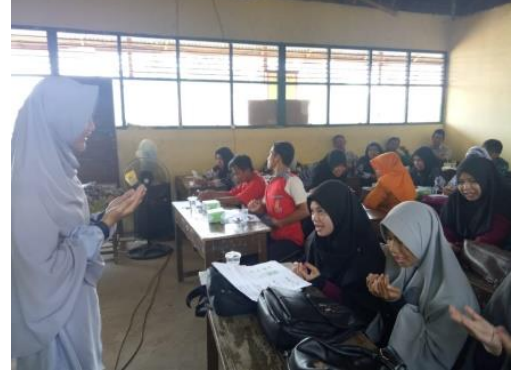

Fig. 3 Examples of Thematic Learning based on 2013 Curriculum

The results of the socialization activities are the teacher's understanding of 2013 Curriculum-based thematic learning for primaryschool teachers getting better. For teachers who teach in classes that have implemented the 2013 curriculum, this activity can be good learning in order to apply the 2013 Curriculum in the classroom.

\section{B. Discussion}

The community service activity raised the title of 2013 Curriculum Based Learning Thematic Training. The location selection of community service activities had taken into account the needs of teachers in the area. Not all schools in Kubu Raya District have implemented the 2013 Curriculum, especially private schools that have just been initiated. This activity is seen as a necessary view because not all teachers have sufficient provision in preparing and implementing learning in accordance with the 2013 curriculum.

SDI Nahdlatul Ulum is one of the schools that have not implemented the 2013 Curriculum. There are several factors that have caused this school not to implement the 2013 Curriculum, 
including the number of teachers who are still lacking and those who do not have a PGSD or PGMI background and incomplete facilities and infrastructure .

The Learning Implementation Plan delivered in this community service activity in accordance with Permendikbud Number 22 Year 2016 which emphasizes in a learning process needs to be multi-interaction. In addition to conveying how to prepare a learning plan, the teacher also presented an example of 2013 curriculum-based thematic learning by one of the community service team members. Examples of learning presented provide an illustration that thematic learning emphasizes more on student involvement in the learning process actively.

The training activities aimed at primaryschool teachers are in line with Mulyasa's opinion (2013: 48) which states that the natural socialization of curriculum implementation is very important, so that all parties involved in its implementation in the field understand the changes that must be carried out in accordance with the main tasks and their respective functions, so that they provide support for changes in the curriculum carried out. The teacher as the main implementer of learning activities is the key to the success of learning. Teachers must prepare themselves to undergo changes in learning; the preparation includes three activities, namely preparation of learning, implementation of learning, and evaluation of learning processes and results. If the three activities are understood, the teacher will have clear learning goals, master the material, have the right method, have sensitivity in choosing the right media, and will have clear standards in providing evaluations.

\section{CONCLUSIONS AND SUGGESTIONS}

\section{A. Conclusions}

Based on the socialization activities in the context of community service with the focus of the 2013 Curriculum Based Learning Training activities, it can be concluded that the teacher's understanding of 2013 Curriculum-based thematic learning for primaryschool teachers is getting better. For teachers who teach in classes that have implemented the 2013 curriculum, this activity can be good learning in order to apply the 2013 Curriculum in the classroom.

B. Suggestions

Some suggestions that can be given given the magnitude of the benefits of community service activities are (1) Community Service activities related to the implementation of the 2013 Curriculum need to continue because not all teachers really understand the implementation of 2013 Curriculumbased learning, (2) serious attention needs from related agencies regarding the conditions of learning support facilities and infrastructure so that the implementation of 2013 Curriculum-based thematic learning can go as expected, and (3) private schools that have just been initiated need to be given more attention to align the quality of schools with other schools.

\section{REFERENCES}

Al-Tabany, Trianto Ibnu Badar. 2014. Mendesain Model Pembelajaran Inovatif,. Progresif, dan Kontekstual. Jakarta: Prenadamedia Group.

E. Mulyasa. 2007. Kurikulum Tingkat Satuan Pendidikan. Bandung: Remaja Rosdakarya.

Kemendikbud. 2015. Panduan Teknis Penyusunan Rencana Pelaksanaan Pembelajaran (RPP) di Sekolah Dasar. Jakarta: Kemendikbud Dirjen Dikdasmen Direktrat Pembinaan Sekolah Dasar.

Kemendikbud . 2016. Permendikbud Nomor 22 Tahun 2016 Tentang Standar Proses Pendidikan Dan Menengah. Jakarta: Kemendikbud

Salinan Lampiran Peraturan Menteri Pendidikan dan Kebudayaan Nomor 22 Tahun 2016 tentang Standar Proses Pendidikan Dasar Dan Menengah.

Sutirjo \& Sri Istuti Mamik. 2005. Tematik: Pembelajaran Efektif dalam Kurikulum 2004. Malang: Bayumedia Publishing.

Undang-Undang Nomor 23 Tahun 2002 tentang Perlindungan Anak (Lembaran Negara Nomor 109 Tahun 2002, Tambahan Lembaran Negara Nomor 4235).

Undang-Undang Nomor 20 Tahun 2003 tentang Sistem Pendidikan Nasional. 